spray, and $4 \mathrm{lb}$. for dusting; but yarrow, pearlwort, woodrush and moss are again resistant. The value of 'Methoxone' has been endorsed by trials at numerous ports and golf clubs.

\section{Mathematical Theory of Tetraploidy}

THE mathematical theory of linkage between genes in a diploid organism is fairly well established. Prof. R. A. Fisher has now developed such a theory for tetraploids, and adumbrated one for hexaploids (Phil. Trans. Roy. Soc., B, 233, 55 ; 1947. 5s. 6d.). As it involves the theory of the partition of numbers, and that of matrices, most geneticists will find it difficult. However, the important conclusion is reached that complete information as to linkage in a tetraploid can only be reached if four different allelomorphs are available at each of two loci, and the limited accuracy of the estimates of linkage so far made is stressed.

\section{Cinnoline Derivatives as Chemotherapeutic Agents for Trypanosoma congolense Infections}

THE authors of the communication under this title published in Nature of April 17, p. 603, state that the concluding phrase should read: ". . . their contamination by hexœestrol, the dihydro derivative of $(V)^{2-6}$ ". The letter should also have included two further references to previous work, as follows : (5) Campbell, Dodds and Lawson, Nature, 142, 1121 (1938) ; (6) Campbell, Dodds and Lawson, Proc. Roy. Soc., B, 128, 253 (1939).

\section{Chemical Research Laboratory, Teddington}

THE Chemical Research Laboratory (Department of Scientific and Industrial Research) at Teddington will be open to visitors during July 1-2. As in 1947, representatives of industry, government departments, universities and technical colleges will be invited to see the Laboratory and the work in progress, and it is hoped that industrial representatives particularly will take advantage of this opportunity. The five main branches of research are : $(a)$ corrosion of metals ; $(b)$ high polymers and plastics; (c) coal tar constituents; $(d)$ organic intermediates; $(e)$ inorganic chemistry. Particular attention is paid at the Laboratory to new techniques of general usefulness. Industrial firms wishing to send representatives should write to the Director, Chemical Research Laboratory, Teddington.

\section{British Museum (Natural History)}

The Coral Gallery of the British Museum (Natural History), which suffered damage during the War, has been reopened. This Gallery had been re-arranged only a short time before the War. The former systematic series of dried specimens of corals are replaced by interesting biological exhibits of reef corals, gorgonians, zoophytes and jellyfish, including a number of photographs and coloured drawings showing what these carnivorous animals look like when alive, how they grow and behave and feed. Their structure is explained, and compared with that of more highly organised animals. A series of jellyfish is shown, including a large 'football' medusa that is new to science.

\section{Summer School in Electron Microscopy}

A SUMmer Schoor in Electron Microscopy is to be held during August 18-24 in the Cavendish Laboratory, Cambridge. The School will provide a grounding in the theory and applications of the electron microscope. It is intended for those who have some familiarity with the instrument and who are already, or in the near future will be, operating it in physical, chemical or biological laboratories. The lectures will deal with the fundamental theory and operating principles of the electron microscope. The various techniques of specimen preparation will be demonstrated, and practised in small groups; the three leading models of instrument will be used. Forms of application for admission can be obtained from G. F. Hickson, Secretary of the Board of ExtraMural Studies, Stuart House, Cambridge ; they must be returned not later than June 12.

\section{Conference on Mechanical Wear}

A SUMMER conference on mechanical wear, to be sponsored by the Massachusetts Institute of Technology, the American Society of Mechanical Engineers, the General Motors Corporation and the Chrysler Corporation will be held in Cambridge, Massachusetts, during June 14-16. The conference will be devoted to consideration of all aspects of wear between solid surfaces-its causes, symptoms and cures. In addition to the engineering aspects of this problem, papers will also be presented on the physical and chemical factors in wear. The speakers will include F. P. Bowden, R. Holm, H. Blok, R. H. Savage, R. G. Larsen and R. W. Dayton. Further particulars can be obtained from Prof. J. T. Burwell, Mechanical Engineering Department, Massachusetts Institute of Technology, Cambridge, Mass., U.S.A.

\section{Institute of Petroleum : Officers}

THE following have been appointed officers for 1948-49 of the Institute of Petroleum : President : E. A. Evans ; Vice-Presidents : Dr. E. B. Evans, H. Hyams, Prof. V. C. Illing, J. A. Oriel, C. A. P. Southwell, H. C. Tett; Hon. Treasurer: G. H. Coxon; Hon. Secretary: C. Chilvers.

\section{Physical Society: Officers}

AT the annual general meeting of the Physical Society on May 5 the following were elected officers for 1948-49 : President, G. I. Finch ; Vice-Presidents who have filled the office of President, Prof. C. H. Lees, Sir Frank Smith, Sir Owen Richardson, Dr. W. H. Eccles, Prof. A. O. Rankine, T. Smith, Prof. Allan Ferguson, Sir Charles Darwin, Prof. E. N. da C. Andrade, Prof. D. Brunt; Vice-Presidents, A. J. Philpot, Dr. W. D. Wright, Dr. W. Jevons, Dr. W. S. Stiles; Honorary Secretaries, C. G. Wynne, H. H. Hopkins; Honorary Foreign Secretary, Prof. E. N. da C. Andrade; Honorary Treasurer, Dr. H. Shaw; Honorary Librarian, Dr. R. W. B. Pearse. All cor. respondence should be addressed to the Secretary/ Editor, Miss A. C. Stickland, 1 Lowther Gardens, Prince Consort Road, London, S.W.7.

\section{Announcements}

UPON resigning his post as head of the Section of Natural Sciences in Unesco, Dr. Joseph Needham has been appointed honorary scientific adviser to the Organisation.

THE Society of German Chemists in the British Zone will hold this year's annual meeting in Hannover during September 1-4. Further details may be obtained from Prof. Werner Fischer, Institut für Anorganische Chemie, Technische Hochschule, Hann. over. 